\title{
A Study on the Internet Usage Pattern of Postgraduate Students of Gulbarga University
}

Vijaykumar Meti*

Department of Journalism and Mass Communication, Gulbarga University, Karnataka, India

\begin{abstract}
Education these days has been the top priority for any family or individual, and no doubt amongst the latest technologies to promote and maintain the education standards the Internet comes first. Internet is not only an access to websites; it is abound of resources of information and knowledge. The resources provided on various websites are indeed very informative and useful for professionals and students as well. The only pre-requisite is the research over the Internet for a specific educational topic, and then this information just needs to be filtered to gain the basic knowledge of what you are looking for. Therefore, these are true Internet resources which deal with every individual's education needs. An attempt has been made to explore and study the consumption pattern in regards to the usage pattern of Internet of postgraduate students in the Gulbarga University. The study also includes student's rationale of Internet usage, and also the impact on them based on the sample of 100 respondents in the selected postgraduate departments of Gulbarga University. The results are discussed and have been observed the attitude of students towards information technology, and the purpose of Internet usage for students. The objective of research was to evaluate weather is there any relationship between the usage of Internet and students academic performance. To better understand the relationship how the Internet affects university students learning the following questions should be answered. What are the benefits of using the Internet as part of a university education" what are the main factors affecting such use? What is the impact of such use on student learning? What does it take to encourage positive attitudes in students toward Internet use? This study tries to answer these questions by exploring the antecedents to and the impacts of Internet use in university education.
\end{abstract}

Keywords: Internet usage; New media; Education; Virtual university; Online education

\section{Introduction}

By the turn of the century, information, including access to the Internet, will be the basis for personal, economic and political advancement. The popular name for the Internet is the information super highway [1]. Whether you want to find the latest financial news, browse through library catalogs, exchange information with colleagues, or join in a lively political debate, the Internet is the tool that will take you beyond telephones, faxes, and isolated computers to a burgeoning networked information frontier [2]. The Internet supplements the traditional tools you use to gather information, Data Graphics, news and correspond with other people. Used skillfully, the Internet shrinks the world and brings information, expertise, and knowledge on nearly every subject imaginable straight to your computer. In particular time, students frequently reported that they were more comfortable talking to their friends using technology such as the Internet or text messaging on their cell phones, than traditional forms of communication such as face-to-face conversations or speaking on the telephone. Anecdotally, a particular client reported that she frequently "froze up" and was unable to have an in-person conversation with her mail friends but had not difficulty "talking" with text via a computer instant messaging program.Education these days has been the top priority for any family or individual person, and no doubt amongst the latest technologies to promote and maintain the education standards the Internet comes first [3]. Internet is not only an access to websites, these days there is knowledge and information on every aspect of the educational world over the Internet. The resources provided on various web pages are indeed very informative and useful for professionals and students related to every field of work. The only pre-requisite is the research over the Internet for a specific educational topic, and then this information just needs to be filtered to gain the basic knowledge of what you are looking for. Therefore, these are true Internet resources which deal with every individual's education needs.Internet has also provided the opportunity to study online [4]. There are virtual universities set up, in which the students can take classes sitting on the computer seat opening the university's website video section according the topics, and then study at home.

The most amazing thing about Internet education is that the international education is no more a chance for only the wealthy and high profile family students because now via Internet no matter if one can afford to study in top most universities, people can easily benefit from the international quality education and gain a respectable university degree sitting at home through the online educational courses provided by the world universities.

Internet education thus also provides the individuals to balance their time according to their own needs, as there is no fixed time to attend the lectures. This also allows the poor class of people to work and study at the same time through Internet education.

\section{Significance of the Study}

At education system, technology is main facilitator that provides to contribute system under requiring needed knowledge. Technology provides us to know and follow all issues with the help of the basic item,

*Corresponding author: Vijaykumar Meti, Department of Journalism and Mass Communication, Gulbarga University, Karnataka, India, E-mail: vijaymeti007@gmail.com

Received February 01, 2014; Accepted 18, 2014; Published February 24, 2014

Citation: Meti V (2014) A Study on the Internet Usage Pattern of Postgraduate Students of Gulbarga University. J Mass Communicat Journalism 4: 182. doi:10.4172/2165-7912.1000182

Copyright: (c) 2014 Meti V. This is an open-access article distributed under the terms of the Creative Commons Attribution License, which permits unrestricted use, distribution, and reproduction in any medium, provided the original author and source are credited. 
Citation: Meti V (2014) A Study on the Internet Usage Pattern of Postgraduate Students of Gulbarga University. J Mass Communicat Journalism 4: 182. doi:10.4172/2165-7912.1000182

Page 2 of 3

which is Internet. Internet is a wide range of supporter by providing all contacts requirements and all types of information, searching facilities with its various digital tools. Technology has impact on education with today's contemporary term as Educational Technology. Within this perspective; computers and Internet are one of the part of the educational technology not replacing all technological developments but it is part of the common concern term. By the way, it is the time to examine what are the attitudes of students' towards Internet that is apart of technology in order to clarify the role of Internet at students' life. Technology especially in education as computers and computer based system requires and concentrates to the how students can learn and use it effective way. Internet and its multi functions are in the roles of delivering information and gathering with easy navigations and paths. Technology and Internet reflect support for new dimensions under the perspective of education especially students' learning-teaching cycle. Through the Internet, students can reach the real experiences of learning. The idea is that learning is constructive process widely accepted: learners do not passively receive information but instead actively construct knowledge. Through these perspectives, Internet applications provide to apply and experience the facilities of constructivist view. In addition to this, Internethelps to facilitate cooperative learning environment. Within the group heterogeneity, positive group interdependence, individual accountability and group processing components of cooperative learning, students can feel the sense of group dynamics and motivation on their learning through the Internet.

\section{Objectives}

The main objectives of the study are, to:

1. Identify attitude of students.

2. Determine the purpose of Internet usage for students.

3. Find out the intensity of Internet usage of students.

4. Evaluate that whether the use of Internet improve the academic performance of students or not.

\section{Methodology}

The research is important to evaluate how the use of Internet will improve the academic performance of the postgraduate students. This research will also bring out some unexpected and serious fact of usage patterns of Internet. The scope of the study comes under the selected postgraduate departments in the Gulbarga University. Survey method has been followed to collect the data from respondents of the study in which 120 questionnaires were distributed to the respondents out of which 100 are duly filled and responded. The study also included the random sampling, questionnaire was found to be an apt tool to collect the relevant data.

\section{Results and Discussion}

Table 1 shows that 52 are male respondents and 48 are female respondents covered in the study. Majority of the respondents covered are in the age group between 26 and 30 years of age, 30.0 per cent of respondents are under 25 years and the rest 07.0 per cent belongs to age group of 31-35 years (Table 2). Each department including Social Science, Arts and Humanities, Science and Technology and Business Studies were equally collected for sampling (Tables 3 and 4). Students asked about the period, since they had been using Internet. The responses varied between up to one year to nine years (Table 5). The analysis shows that 27 per cent of respondents use Internet usage was

\begin{tabular}{|c|c|c|}
\hline Sex & Respondents & Per cent \\
\hline Male & 52 & 52.0 \\
\hline Female & 48 & 48.0 \\
\hline Total & 100 & 100.0 \\
\hline
\end{tabular}

Table 1: Gender of the Respondents.

\begin{tabular}{|c|c|c|}
\hline Age (in years) & Respondents & Per cent \\
\hline Under 25 & 30 & 30.0 \\
\hline $26-30$ & 63 & 63.0 \\
\hline $31-35$ & 07 & 07.0 \\
\hline Total & 100 & 100.0 \\
\hline
\end{tabular}

Table 2: Age of the Respondents.

\begin{tabular}{|c|c|c|}
\hline Faculties & Respondents & Per cent \\
\hline Social Science & 25 & 25.0 \\
\hline Arts and Humanities & 25 & 25.0 \\
\hline Science and Technology & 25 & 25.0 \\
\hline Business Studies & 25 & 25.0 \\
\hline Total & 100 & 100.0 \\
\hline
\end{tabular}

Table 3: Respondents Faculties.

\begin{tabular}{|c|c|c|}
\hline Use Internet & Respondents & Per cent \\
\hline Yes & 100 & 100.0 \\
\hline No & 0 & 0 \\
\hline Total & 100 & 100.0 \\
\hline
\end{tabular}

Table 4: Respondents Use Internet.

\begin{tabular}{|c|c|c|}
\hline Period & Respondents & Percent \\
\hline Up to 1 year & 27 & 27.0 \\
\hline 2 years & 24 & 24.0 \\
\hline 3 years & 19 & 19.0 \\
\hline 4 years & 14 & 14.0 \\
\hline 5 years or more & 19 & 19.0 \\
\hline Total & 100 & 100.0 \\
\hline
\end{tabular}

Table 5: Respondents Experience as Internet User.

\begin{tabular}{|c|c|c|}
\hline Devices & Respondents & Percent \\
\hline Own Computer/Laptop & 09 & 05.0 \\
\hline $\begin{array}{c}\text { University Computer } \\
\text { Labs }\end{array}$ & 48 & 48.0 \\
\hline Smartphones & 28 & 28.0 \\
\hline Cyber Cafe & 15 & 15.0 \\
\hline Total & 100 & 100.0 \\
\hline
\end{tabular}

Table 6: Respondents Usually Access Internet.

up to one year. 24 per cent students had two year experience while 19 per cent had three year and 14 per cent had four year experience of using Internet. 19 per cent were using Internet for five or more years (Table 6). According to the above table 4, nearly half of the respondents (48 per cent) found university computer labs useful to access Internet usually. 28.0 per cent access Internet using their smart-phones, while 15.0 per cent use cyber café or Internet centers and 09.0 per cent respondents access Internet using their own computers, which also including laptops (Table 7). According to the above table 5, less than half of the respondents found to browse Internet for two and three hours ( 48 per cent). 18.0 per cent claims to browse Internet less than two hours, 15.0 per cent browse for $4-5$ hours and 19.0 per cent members use Internet for more than 5 hours per day (Table 8). The above table shows that 62.0 per cent of respondents use Social Networking followed by Academic Notes (56.0 per cent), Chat Rooms/Video Calls (49.0 per cent), Online Journals (46.0 per cent), E-Mail (43.0 per cent), while 


\begin{tabular}{|c|c|c|}
\hline Hours & Respondents & Percent \\
\hline Less than 2 hours & 18 & 18.0 \\
\hline 2-3 hours & 48 & 48.0 \\
\hline 4-5 hours & 15 & 15.0 \\
\hline More than 5 hours & 19 & 19.0 \\
\hline Total & 100 & 100.0 \\
\hline
\end{tabular}

Table 7: Hours Spent on Browsing Internet (per day).

\begin{tabular}{|c|c|c|c|}
\hline Types of Contents & Yes & No & Total \\
\hline Academic Notes & 56 & 44 & 100 \\
\hline Chat Rooms/Video Calls & 49 & 51 & 100 \\
\hline Online Forum & 41 & 59 & 100 \\
\hline E-Mail & 43 & 57 & 100 \\
\hline Online Journals & 46 & 54 & 100 \\
\hline Social Networking & 62 & 38 & 100 \\
\hline Online Games & 22 & 78 & 100 \\
\hline
\end{tabular}

Table 8: Type of Content Viewed in Internet.

\begin{tabular}{|c|c|c|c|}
\hline $\begin{array}{c}\text { Reason for Internet } \\
\text { use }\end{array}$ & Yes & No & Total \\
\hline $\begin{array}{c}\text { To Prepare Class } \\
\text { Assignment }\end{array}$ & 88 & 12 & 100 \\
\hline $\begin{array}{c}\text { To Update Knowledge } \\
\text { For Communication }\end{array}$ & 53 & 47 & 100 \\
\hline For Entertainment & 23 & 77 & 100 \\
\hline $\begin{array}{c}\text { To Prepare For } \\
\text { Examinations }\end{array}$ & 51 & 28 & 100 \\
\hline To Read News & 37 & 49 & 100 \\
\hline To Download Software & 27 & 63 & 100 \\
\hline To Purchase Items & 08 & 73 & 100 \\
\hline For Other Reasons & 31 & 92 & 100 \\
\hline
\end{tabular}

Table 9: Reasons for Internet use.

\begin{tabular}{|c|c|c|}
\hline Performance & Respondents & Per cent \\
\hline Improved & 68 & 68.0 \\
\hline Neutral & 23 & 23.0 \\
\hline Not Improved & 9 & 09.0 \\
\hline Total & 100 & 100.0 \\
\hline
\end{tabular}

Table 10: Academic Performance Using Internet.

41.0 per cent ask questions for experts in Online Forum and 22.0 per cent of respondents indicate online games (Table 9). The students were asked to mention the reasons for using Internet. 88 users mentioned that they were using Internet for preparing class assignments, 53 users pointed out that they were using it to update their knowledge, 23 users were using it for communication purposes, 72 users mentioned that they were using it for entertainment, 51 users were using it for the examinationpreparation, 37 users were using it for reading news, 27 users mentioned that they were using it to download software, 13 users were using it for purchasing items using online shopping sites, while 31 users were using it for their specific purposes such as online job searching \& application, career development, spending leisure time, chatting, communities talk \& forum discussion, poetry reading, to know about international political \& global affairs, and sports updates (Table 10). According to the above table respondents says that using Internet for academic study is very useful. More than half (68 percent) has believes that Internet has improved their academic performance about 23 per cent are in neutral status while the rest 9 per cent believes that Internet has not improved their academic performance.

\section{Conclusion}

This study was intended to learn if Internet plays beneficial role in the education field of postgraduate students or on the contrary it is distraction from subjects. If Internet was helpful in the studies for students then what the society or the university is doing in order to help the student? Also the study wanted to know if postgraduate students use Internet for the purpose of education. By the end of the research we learned that Internet does play vital role in the education field of the students. The study result showed that those students who are literate in technology and have access to the Internet can earn well than those who do not use Internet at all or uses it for not educational purposes. We learned that students gain from Internet all needed information and easily broaden their understandings. Internet use has become common in academic quarters very recently. Most of the university students have started the use of Internet since last one to two years. In addition to a central Internet lab the students have Internet access in their departments.

From these figures, the most significant trend is the nearly quarter percentage of students who have access to the Internet using their smartphone or tablet, which shows the ability of university students to have mobile Internet accessibility all time. Internet cafés also have a significant market share but after university and handheld devices. The study also reveals that students with no computers found university computer lab very useful and comfortable with high-speed Internet. But those who own computer also showed their desire to use Internet on campus if there is chance to use it wireless at any time throughout the day.

The survey clearly shows that, students are making use of the Internet for course related reading and research needs. Only one-fourth students use it for entertainment purpose. Ease of work and time saving are the reasons of Internet use among university students. Authenticity of information on the Internet could attract only a small number of students. As we know, these days Internet is one of the most powerful mass media. Where multimedia, television, radio and print media is joined and used in the Internet in an online method. In the education point of view students use Internet for the purpose of downloading e-books, reading scientific articles, asking questions for experts in the online forums and write e-mails, blogs and share knowledge to others. But in the non-education point of view, students use the Internet for the purpose of entertainment such as playing online games, making virtual friends on social networking sites like Facebook, Twitter, Google+ etc., and also use instant messenger, chat rooms and video calls.

As the study had shown, more number of students depends on the Internet for their academic needs than in the past. Knowing the importance of Internet in the academic education, the university has provided easy opportunity for students to use Internet at the university campus. A fully-fledged computer lab with high-speed Internet connection in the central library and also many departments has computer labs in the university. The university has arranged training programs to orientate the students and teachers to the hidden potential of this technology. Elements on basic and advanced techniques had been included in the curricula of several departments. Teaching and non-teaching staff encourage Internet usage among students.

\section{References}

1. Anunobi CV (2006) Dynamics of Internet usage: A case of students of the Federal University of Technology Owerri (FUTO) Nigeria. Educational Research and Reviews 1: 192-195.

2. Brownlow M (2007) Email and webmail statistics

3. Asan A, Koca N (2006) An analysis of students' attitudes towards Internet Fourth International Conference on Multimedia and Information and Communication Technologies in Education, Seville, Spain.

4. Bennett G (2001) Who is on the Internet? IDEA Personal Trainer 12: 6-12. 